\title{
Assessment of oestrogen receptor content of breast carcinoma by immunohistochemical techniques on fixed and frozen tissue and by biochemical ligand binding assay
}

\author{
D A Paterson, C P Reid, T J Anderson, R A Hawkins
}

\begin{abstract}
The oestrogen receptor content of 61 breast carcinomas was assessed by biochemical ligand binding assay and three immunohistochemical techniques-a frozen section method (Abbott ER-ICA) and on parafin wax sections after fixation by two methods. The two fixatives used were Carson's buffered formalin and methacarn, and a DNAse pretreatment of sections was used. Overall agreement for the immunohistochemical methods with the ligand binding technique were $95 \%, 85 \%$, and $86 \%$ for the frozen, formalin, and methacarn methods, respectively. A semiquantitative staining score was performed and all three methods gave significant correlations of staining scores with biochemical ligand binding values. The frozen section method was best $(\mathbf{r}=0.88)$ with the fixed tissue methods yielding poorer correlation coefficients. Several factors affected staining, including the nature of the fixative and variable activity of DNAse.

It is concluded that immunohistochemical assessment of oestrogen receptor content on fixed tissue provides acceptable qualitative information but that standardisation of protocols for tissue processing will be necessary for optimal utility and especially for quantitative assessments.
\end{abstract}

The presence of oestrogen receptors in breast carcinomas is an independent prognostic factor $^{1}$ and a predictor of likely response to hormonal treatment. ${ }^{2}$ Biochemical ligand binding techniques are the standard methods for assessment of oestrogen receptor and yield a numerical value for clinical use. The techniques, however, have disadvantages as they require fresh tissue and can take no direct account of either the proportion of carcinoma in the sample or the heterogeneity of oestrogen receptor expression within the tissue submitted for analysis.

Immunohistochemical techniques using monoclonal antibodies allow the proportion of carcinoma in the tissue to be assessed directly and the heterogeneity of oestrogen receptor occurrence. Studies using both frozen sections $^{3-11}$ and fixed tissues ${ }^{12-18}$ have reported good correlations of immunohistochemical assessments with the results of ligand binding assays. Immunohistochemical methods, which can be applied to fixed tissues, are the most convenient for use within a routine diagnostic service. To date, however, the fixation, enzymatic pretreatments, detection systems, and methods of quantitation for these methods have not been standardised and the ideal choice of a method for routine use is uncertain.

In the search for an optimal method for routine use we compared the results of two immunohistochemical methods for fixed tissues both with each other and with the Abbott ER-ICA frozen section technique. ${ }^{19}$ All three immunohistochemical methods were also compared with ligand binding assay results for the same tumours.

\section{Methods}

Tissue specimens from 70 patients submitted to the department as "carcinomas" were studied. The specimens were received fresh and included diagnostic biopsy specimens, wide local excisions, and mastectomies. They were transported to the laboratory on ice, examined macroscopically, and representative blocks were taken from adjacent areas for histological diagnosis, ligand binding assay, and the three immunohistochemical methods.

Histological diagnosis was performed on 4 $\mu \mathrm{m}$ sections stained with haemotoxylin and eosin cut from representative tumour blocks after formalin fixation, routine processing, and paraffin wax embedding. At microscopy the presence or absence of carcinoma was confirmed.

BIOCHEMICAL LIGAND BINDING ASSAY

Biochemical oestrogen receptor assay was carried out by saturation analysis on tumour extracts with separation of free and bound hormone by dextran coated charcoal adsorption. ${ }^{20}$ The dissociation constant of binding and receptor concentration were calculated by Scatchard analysis and the results expressed as $\mathrm{fmol} / \mathrm{mg}$ of cytosol protein. Tumours with oestrogen receptor values of equal to or $>5$ fmol/mg cytosol protein were considered to be biochemically positive.

\section{IMMUNOHISTOCHEMICAL STAINING}

The three immunohistochemical staining methods used are summarised in table 1. For each method the same primary antibody, monoclonal rat IgG to human oestrogen recep- 
Table 1 Summary of three immunohistochemical oestrogen receptor methods

\begin{tabular}{|c|c|c|}
\hline Method 1 & Method 2 & Method 3 \\
\hline Fresh tumour blocks frozen in liquid nitrogen & $\begin{array}{l}\text { Fresh tumour blocks fixed in Carson's buffered } \\
\text { formalin at } 4^{\circ} \mathrm{C} \text { for } 24-48 \text { hours }\end{array}$ & $\begin{array}{l}\text { Fresh tumour blocks fixed in freshly prepared meth- } \\
\text { acarn (methnol: chloroform: acetic acid } 6: 3: 1 \text { ) at } 4^{\circ} \mathrm{C} \\
\text { for } 4-24 \text { hours }\end{array}$ \\
\hline $\begin{array}{l}4 \mu \mathrm{m} \text { cryostat sections cut and mounted on adhesive } \\
\text { pretreated slides }\end{array}$ & $\begin{array}{l}\text { Routine processing, paraffin wax embedding, } 4 \mu \mathrm{m} \\
\text { sections cut and dewaxed in xylene }\end{array}$ & $\begin{array}{l}\text { Routine processing, paraffin wax embedding, } 4 \mu \mathrm{m} \\
\text { sections cut, and dewaxed in xylene }\end{array}$ \\
\hline $\begin{array}{l}\text { Fixation on slides in } 3.7 \% \text { formaldehyde: phosphate } \\
\text { buffered saline (PBS), methanol at }-10^{\circ} \mathrm{C} \text { and } \\
\text { acetone at }-10^{\circ} \mathrm{C}\end{array}$ & $\begin{array}{l}\text { Pretreatment with DNAse(Sigma Pharmaceuticals) } \\
\text { at } 5 \mu \mathrm{g} / \mathrm{ml} \text { in TRIS buffer for one hour }\end{array}$ & $\begin{array}{l}\text { Pretreatment with DNAse (Sigma Pharmaceuticals) } \\
\text { at } 3 \mathrm{mg} / \mathrm{ml} \text { in TRIS buffer for } 7 \text { minutes }\end{array}$ \\
\hline $\begin{array}{l}15 \text { minute incubation with blocking reagent (normal } \\
\text { goat serum in phosphate buffer) }\end{array}$ & 15 minute incubation with blocking reagent & 15 minute incubation with blocking reagent \\
\hline 30 minute incubation with primary antibody & Overnight incubation with the primary antibody & Overnight incubation with the primary antibody \\
\hline $\begin{array}{l}30 \text { minute incubation with bridging antibody (Goat } \\
\text { anti-rat at } 10 \mu \mathrm{g} / \mathrm{ml} \text { in phosphate buffer) }\end{array}$ & $\begin{array}{l}\text { Further processing with bridging antibody, PAP } \\
\text { complex, and counterstaining as for method } 1\end{array}$ & $\begin{array}{l}5 \text { minute incubation with normal goat serum 1:10 in } \\
\text { PBS }\end{array}$ \\
\hline 30 minute incubation with PAP complex & & $\begin{array}{l}30 \text { minute incubation with biotinylated goat anti-rat } \\
\text { Ig (Sigma Pharmaceuticals) at } 1: 50 \text { in goat serum to } \\
\text { PBS } 1: 10\end{array}$ \\
\hline $\begin{array}{l}\text { Incubation with: chromagen substrate solution } \\
\text { (diaminobenzidine (DAB): HCl in citrate phos- } \\
\text { phate buffer containing hydrogen peroxide) }\end{array}$ & & $\begin{array}{l}15 \text { minute incubation with streptavidin-biotin com- } \\
\text { plex (Amersham International) at } 1: 200 \text { in PBS }\end{array}$ \\
\hline Methyl green counterstain & & $\begin{array}{l}\text { DAB detection and methyl green counterstain as } \\
\text { method } 1\end{array}$ \\
\hline
\end{tabular}

tor (Abbott Laboratories) ${ }^{19}$ was used. Where sufficient tumour tissue was available, tissue was processed by more than one or all three of the methods to allow comparisons to be made.

\section{Method 1}

Immunohistochemical staining was performed on frozen sections as recommended in the Abbott ER-ICA Kit. ${ }^{19}$ This entailed a strict fixation schedule on slides coated with gel and uses a peroxidase-antiperoxidase (PAP) detection system.

\section{Method 2}

The first fixed tissue method entailed fixation of tumour blocks in monobasic sodium phosphate buffered formalin (Carson's ${ }^{21}$ ) at $4^{\circ} \mathrm{C}$ for between $24-48$ hours before standard processing for paraffin wax sections. A DNAse pretreatment, as suggested by Shintaku and Said, ${ }^{15}$ was used before overnight incubation with the primary antibody and a PAP detection system.

\section{Method 3}

The second fixed tissue method entailed fixation in freshly prepared methacarn (methanol: chloroform: acetic acid $6: 3: 1$ ) at $4^{\circ} \mathrm{C}$ for four to 24 hours. A DNAse pretreatment was again used, ${ }^{15}$ but a streptavidin-biotin detection system (Amersham International) was used this time.

Negative controls consisted of using normal rat immunoglobulin in place of the primary antibody to human oestrogen receptor. Two positive controls were also included, the first was the control slides supplied by Abbott, the

Table 2 Scoring system based on intensity of staining and estimated percentage of staining cells

\begin{tabular}{lllll}
\hline \multirow{2}{*}{$\begin{array}{l}\text { Percentage of carcinoma } \\
\text { showing each staining intensity }\end{array}$} & \multicolumn{4}{l}{ Staining intensity } \\
\cline { 2 - 5 } & Negative & Weak & Moderate & Strong \\
\hline 0 & 0 & 0 & 0 & 0 \\
$<10$ & 0 & 0 & 0 & 2 \\
$10-25$ & 0 & 1 & 2 & 4 \\
$26-75$ & 0 & 2 & 4 & 8 \\
$76-90$ & 0 & 3 & 6 & 12 \\
$>90$ & 0 & 4 & 8 & 16 \\
\hline
\end{tabular}

second was a breast carcinoma known to be both biochemcially and immunohistochemcially oestrogen receptor rich (biochemical value $419 \mathrm{fmol} / \mathrm{mg}$ cytosol protein).

SCORING OF IMMUNOHISTOCHEMICAL STAINING Immunohistochemical oestrogen receptor staining was seen as a brown staining of variable intensity confined to the nucleus. For quantitation of immunohistochemical results a semiquantitative scoring system was devised. This was broadly similar to other published scoring systems $s^{310121618}$ taking account of the intensity of staining and the visually estimated percentage of malignant nuclei showing each staining intensity. Four intensities were recognised-namely, negative, weak, moderate and strong, and the percentages observed divided into the six groups of $0,<10 \%, 10-25 \%, 26-$ $75 \%, 76-90 \%$ and $>90 \%$. The stronger staining intensities were given more heavily weighted scores (table 2). The final score was obtained by adding up the proportional scores giving a possible maximum of 16 . All the immunohistochemically stained slides were scored independently by two observers (CR and DP), who were unaware of each others' results and the results of the ligand binding assays. The final score used for subsequent correlations was a mean of the two scores so produced. A case with a score of greater than zero was considered to show clinically important immunohistochemical oestrogen receptor positivity.

\section{Results}

HISTOPATHOLOGY

From a total of 70 biopsy specimens, 61 carcinomas were confirmed on histological examination, eight of these cases contained non-invasive carcinoma only. The remaining nine specimens were composed of one case of fat necrosis, five of complex sclerosing lesions, a Phyllodes tumour and two primary breast sarcomas. These non-carcinomatous lesions were excluded from further study. 
Table 3 Immunohistochemical results for methods 1-3

\begin{tabular}{llll}
\hline Immunohistochemical oestrogen receptor status & $\begin{array}{l}\text { Method 1 } \\
\text { Number (\%) }\end{array}$ & $\begin{array}{l}\text { Method 2 } \\
\text { Number (\%) }\end{array}$ & $\begin{array}{l}\text { Method 3 } \\
\text { Number (\%) }\end{array}$ \\
\hline Oestrogen receptor positive & $25(60)$ & $27(59)$ & $25(53)$ \\
Oestrogen receptor negative & $17(40)$ & $20(43)$ & $22(47)$ \\
Total & $42(100)$ & $46(100)$ & $47(100)$ \\
\hline
\end{tabular}

BIOCHEMICAL RESULTS

Ligand binding oestrogen receptor values were available for 53 of the total 61 carcinomas. Of the non-assayed eight cases, four patients with invasive carcinoma had received tamoxifen treatment before biopsy and in the other four cases no cancerous tissue was submitted for analysis. Thirty six of the 53 cases $(68 \%)$ were oestrogen receptor positive $(>5 \mathrm{fmol} / \mathrm{mg}$ protein); $17(32 \%$ ) were negative ( $<5 \mathrm{fmol} / \mathrm{mg}$ protein).

\section{IMMUNOHISTOCHEMICAL RESULTS}

The results of histochemical staining for each method are shown in table 3. Of the total 61 carcinomas, histochemical assessment of oestrogen receptor was performed on 42 cases by method 1 , on 46 cases by method 2 , and on 47 cases by method 3. For each method, respectively, 25 of $42(60 \%), 27$ of $46(59 \%)$, and 25 of $47(53 \%)$ were immunohistochemically oestrogen receptor positive. Examples of staining are shown in figs 1 and 2 .

\section{IMMUNOHISTOCHEMICAL AND BIOCHEMICAL CORRELATIONS}

Biochemical values from adjacent areas were available for 37,40 , and 43 cases, respectively,

Figure 1 Invasive carcinoma showing strong,

immunohistochemical oestrogen receptor staining; method 2 (Carson's fixed.)

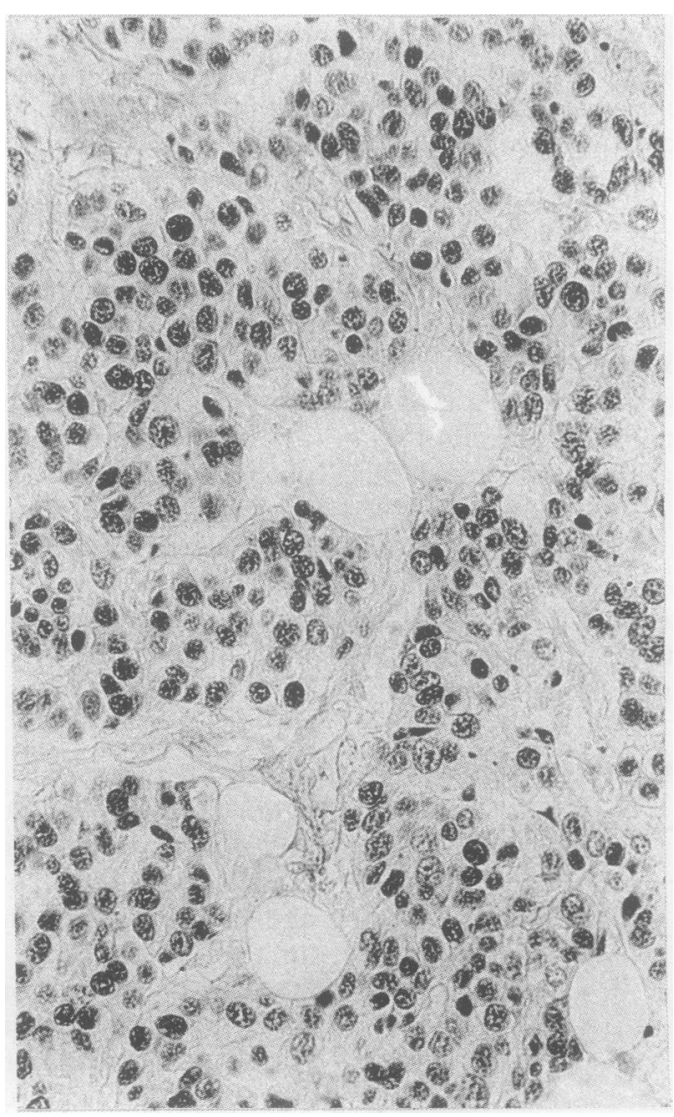

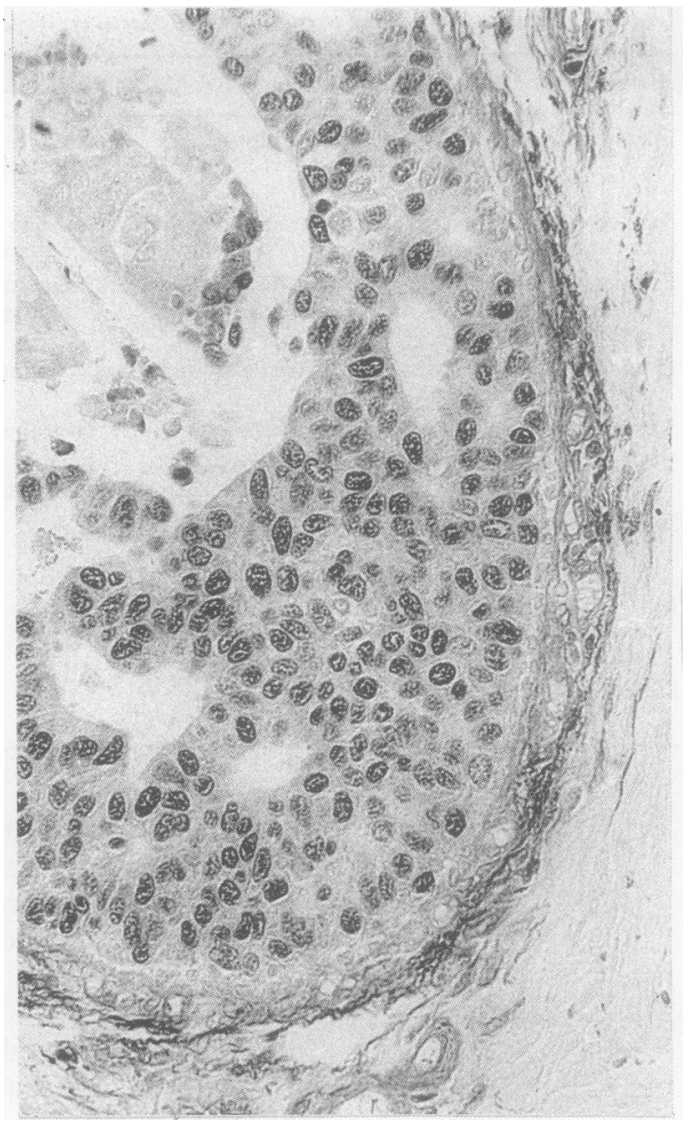

Figure 2 In situ carcinoma with central comedo necrosis showing strong oestrogen receptor staining. The nonspecific cytoplasmic endothelial staining present was also seen on negative control slides and was due to endogenous peroxidase that was not blocked; method 3 (Methacarn fixed.)

from the cases processed by immunohistochemical methods $1-3$. Results of concordance of immunohistochemical receptor positivity with biochemical oestrogen receptor positivity are shown in table 4 , with percentage overall concordance of $95 \%, 85 \%$, and $86 \%$ for methods $1-3$, respectively. If it is assumed that the biochemical results are the true "standard" then the percentage of false negative results totalled $5 \%, 10 \%$, and $11 \%$ for the frozen, formalin, and methacarn treated methods, respectively. These false negative results came from eight cases. The two frozen section false negative cases both had low biochemical receptor values of 12 and $17 \mathrm{fmol} / \mathrm{mg}$ protein, and fixed tissue immunohistochemical staining for both cases was also negative. Two further negative cases assessed by fixed tissue methods alone also had relatively low biochemical values of 21 and $22 \mathrm{fmol} / \mathrm{mg}$ protein. The remaining four fixed tissue, false negative cases showed frozen section immunohistochemical positivity and had biochemical values of between 22 and $247 \mathrm{fmol} / \mathrm{mg}$ protein, suggesting some failure of the fixed tissue immunohistochemical method.

Conversely, the false positive rates were $0 \%$, $4 \%$, and $2 \%$ for the three methods, respectively. These arose from two cases. Review of control histological slides from the tissue submitted for biochemical analysis in these cases showed that one contained only non-invasive carcinoma, while the other was poorly cellular 
Table 4 Concordance of biochemical oestrogen receptor positivity with immunohistochemical oestrogen receptor positivity for methods 1-3

\begin{tabular}{|c|c|c|c|c|c|c|}
\hline & \multicolumn{6}{|c|}{ Immunohistochemical oestrogen receptor status } \\
\hline & \multicolumn{2}{|c|}{ Method 1} & \multicolumn{2}{|c|}{ Method 2} & \multicolumn{2}{|c|}{ Method 3} \\
\hline & + & - & + & - & + & - \\
\hline $\begin{array}{l}\text { Biochemical oestrogen receptor values } \\
\text { positive } \\
\text { negative }\end{array}$ & $\begin{array}{r}22 \\
0\end{array}$ & $\begin{array}{r}2 \\
13\end{array}$ & $\begin{array}{r}23 \\
2\end{array}$ & $\begin{array}{r}4 \\
11\end{array}$ & $\begin{array}{r}24 \\
1\end{array}$ & $\begin{array}{r}5 \\
13\end{array}$ \\
\hline Total number & 37 & & 40 & & 43 & \\
\hline Percentage concordance & $95 \%$ & & $85 \%$ & & $86 \%$ & \\
\hline
\end{tabular}

with less than $20 \%$ of the tissue submitted comprising carcinoma. This suggested some failure of the biochemical method.

Correlations of biochemical results with the semiquantitative staining scores for each method are shown in figs 3-5. Analysis of these results by Spearman correlation coefficients yielded significant correlations for method 1 , $\mathrm{r}=0.87, \mathrm{p}<0.0001$; for method $2, \mathrm{r}=0.61$, $\mathrm{p}<0.0001$; for method $3, \mathrm{r}=0.68, \mathrm{p}<$ 0.0001 . The frozen section method yielded the most significant correlation, with the results of the two fixed tissue methods lower than other published ranges. $^{35101118}$

\section{CORRELATION OF FROZEN SECTION} IMMUNOHISTOCHEMICAL RESULTS WITH FIXED TISSUE METHODS

For larger lesions, tissue was processed by more than one immunohistochemical method. This yielded 32 cases for each fixed tissue method for direct comparison with the frozen section method. As the frozen section method is the best characterised and gave the best correlation with biochemical values the results by this method were considered to be "correct" values. The concordances of positive results on fixed tissue methods with frozen section were $78 \%$ and $81 \%$ for Carson's and methacarn fixed tissues, respectively (table 5).

\section{Discussion}

This study has shown that oestrogen receptor content can be assessed by immunohistochemistry using tissues fixed in either Carson's

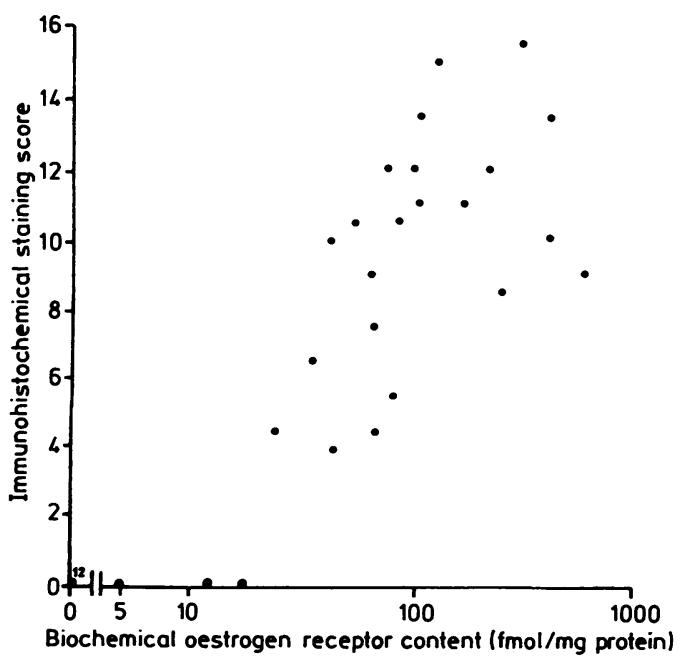

Figure 3 Correlation of histochemical staining score for method 1 with biochemical oestrogen receptor value.

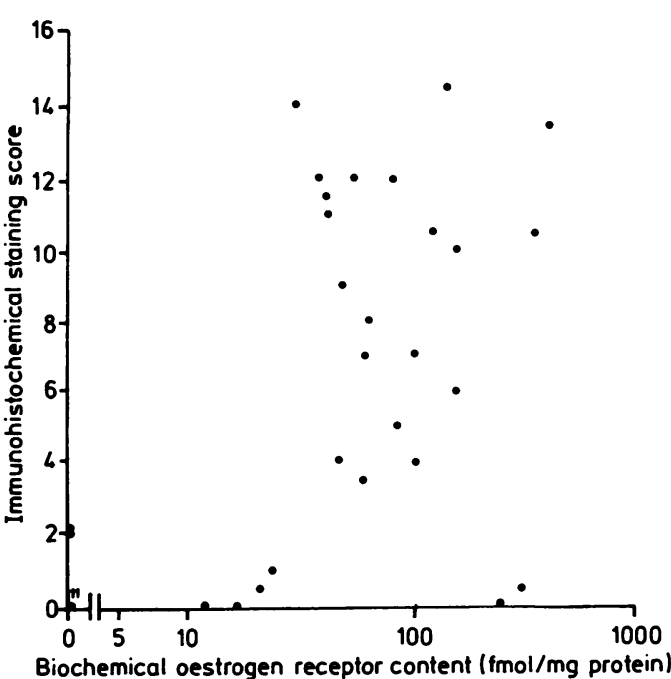

Figure 4 Correlation of histochemical staining score for method 2 with biochemical oestrogen receptor value.

buffered formalin or methacarn, as well as by the frozen section method. Qualitative assessment of the presence of oestrogen receptor for each immunohistochemical method gave overall concordance with biochemical values comparable with other published values in the range $65-93 \%$, 389131517 with the frozen section method giving the best results (95\%).

Quantitative assessment of immunohistochemical oestrogen receptor values was performed using a semiquantitative staining score. This system, as have others, ${ }^{346791214-1618}$ takes account of staining intensity and grouped proportions of cells stained, but is not designed as an absolute method of quantitation. Other more detailed methods have been published, ${ }^{510}$ some including image analysis, ${ }^{11}$ and these are likely to be more accurate. Despite this, significant correlations of staining scores with biochemical values were achieved for each of the three methods. The frozen section method again gave the best result with a high correlation coefficient of 0.88 comparable with other published coefficients in the range of 0.65 to $0.91 .^{351011} 18$ The results for the two fixed tissue methods, though significant, were lower, however, than other published coefficients,

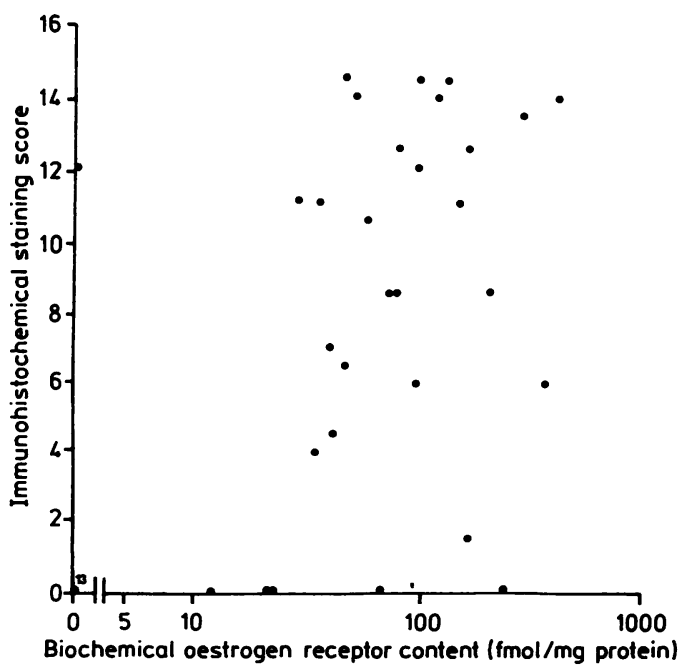

Figure 5 Correlation of histochemical staining score for method 3 with biochemical oestrogen receptor value. 
Table 5 Concordance of frozen section immunohistochemical oestrogen receptor positivity with both tissue methods

\begin{tabular}{|c|c|c|c|c|}
\hline & \multicolumn{2}{|c|}{ Method 2} & \multicolumn{2}{|c|}{ Method 3} \\
\hline & + & - & + & - \\
\hline $\begin{array}{c}\text { Method } 1 \\
\text { positive } \\
\text { negative }\end{array}$ & $\begin{array}{r}16 \\
2\end{array}$ & $\begin{array}{l}5 \\
9\end{array}$ & $\begin{array}{r}16 \\
4\end{array}$ & $\begin{array}{r}2 \\
10\end{array}$ \\
\hline Total & \multicolumn{2}{|l|}{32} & \multicolumn{2}{|l|}{32} \\
\hline Percentage correct & \multicolumn{2}{|c|}{$25 / 32(78)$} & \multicolumn{2}{|c|}{$26 / 32(81)$} \\
\hline
\end{tabular}

indicating that these methods are less useful for quantitation. This reduced correlation by the two fixed tissue methods seems due partly to staining inconsistencies that resulted in increased numbers of false negative results, but also due to cases with moderate biochemical values being assigned higher staining scores.

The possible reasons for staining inconsistencies with immunohistochemical methods that may lead to poor correlations with biochemical values have been highlighted by Parl and Posey. ${ }^{8}$ Possible causes for false negative results include changes in oestrogen receptor by fixation, natural degradation of the oestrogen receptor with delay in fixation, heterogeneity in the oestrogen receptor population, heterogeneity of oestrogen receptor expression in the carcinoma, poor sensitivity of immunohistochemical methods at low receptor values and suboptimal exposure of oestrogen receptor due to variable activity of any enzymatic pretreatment. Many of these factors will clearly be influenced by variables that have not been standardised among the published fixed tissue immunohistochemical methods, summarised in table 6. These include the composition of the fixative, the duration of fixation, fixation temperature, enzymatic pretreatments and the detection systems. Unless and until agreement to standardise these variables is reached, then fixed tissue immunohistochemical oestrogen receptor assessment will not be as useful, either qualitatively or quantitatively, as the biochemical ligand binding assay. This, by comparison, is a standardised method, subjected to quality control, and has achieved a good degree of interlaboratory agreement. ${ }^{22}$

The choice of the most appropriate immunohistochemical protocol for standard use on fixed tissues is still not clear, but several aspects of the method can be highlighted. Firstly, in our study fixation in methacarn gave better results than formalin fixation. The improved staining with methacarn was probably because it penetrates tissues more rapidly than formalin and this results in better preservation of oestrogen receptors. Secondly, to slow natural degradation of oestrogen receptors fixation was performed at low temperature for both methods. Thirdly, in certain instances staining inconsistency was due to variable activity of DNAse. This problem has also been identified and modification suggested by the authors of this method. ${ }^{23}$

Though the fixed tissue immunohistochemical methods have not yet achieved the level of standardisation to permit accurate and consistent quantitation, they are already of confirmed clinical value for qualitative assessment ${ }^{24}$ and have advantages over frozen section methods. They yield sections of better morphological quality, reduce the health risk intrinsic in the use of fresh tissue, enable greater areas of the lesion to be evaluated and thus allow the importance of heterogeneity of receptor expression to be more fully assessed. Furthermore, fixed tissue immunohistochemical oestrogen receptor assessment can be particularly applied to small or occult lesions where routine processing of all the limited tissue available has been necessary for diagnosis. With the planned establishment of more widespread breast cancer screening by mammography, ${ }^{25}$ such specimens are likely to become more numerous.

We thank the surgical and theatre staff at Longmore Hospital, Edinburgh, for their continued cooperation, Mrs Lind Ferrigan for technical work, Miss Marion Simpson for the statistical analysis and Mrs Joyce Garson for preparation of the manuscript.

Financial support for this work is acknowledged from the Cancer Research Campaign (CPR, TJA) and Lothian Health Board (RAH).

1 Clark GM, McGuire WL. Prognostic factors in primary breast cancer. Breast Cancer Treat Res 1983;3(Supp 1):69.

2 Hawkins RA, Roberts MM, Forrest APM. Oestrogen receptors and breast cancer: current status. Br J Surg 1980 67:153-69.

3 Hawkins RA, Sangster K, Krajewski A. Histochemical detection of oestrogen receptors in breast carcinoma: successful technique. Br J Cancer 1986;53:407-10.

4 Reiner A, Spona J, Reiner G, et al. Oestrogen receptor analysis on biopsies and fine-needle aspirates from human analysis on biopsies and fine-needle aspirates from

5 McCarty KS (Jr), Miller LS, Cox EB, Konrath J, McCarty $\mathrm{KS}$ (Sr). Estrogen receptor analyses, correlation of bioKS (Sr). Estrogen receptor analyses, correlation of biochemical and immunohistochemical methods using mono1983;109:716-21.

6 Berger U, Wilson P, McClelland RA, Davidson J, Coombes RC. Correlation of immunocytochemically demonstrated estrogen receptor distribution and histopathologic features in primary breast cancer. Hum Pathol 1987, 18:1263-7.

Table 6 Variables in published fixed tissue immunohistochemical methods

\begin{tabular}{|c|c|c|c|c|c|}
\hline Author & Fixative & $\begin{array}{l}\text { Fixation } \\
\text { time (hours) }\end{array}$ & $\begin{array}{l}\text { Fixation } \\
\text { temperature }\end{array}$ & Pretreatment & $\begin{array}{l}\text { Detection } \\
\text { system }\end{array}$ \\
\hline $\begin{array}{l}\text { Shimada et al }(1985)^{13} \\
\text { Poulsen et al }(1985)^{17} \\
\text { Poulsen et al }(1986)^{18} \\
\text { De Rosa et al }(1987)^{14} \\
\text { Shintaku et al }(1987)^{15} \\
\text { Marchetti et al }(1987)^{16} \\
\text { Cheng et al }(1988)^{12}\end{array}$ & $\begin{array}{l}10 \% \text { buffered formalin } \\
\text { Bouin's solution } \\
4 \% \text { buffered formalin } \\
\text { Bouin's solution } 10 \% \text { buffered formalin } \\
10 \% \text { buffered formalin } \\
\text { Fl fixative } 10 \% \text { buffered formalin, carnoy } \\
10 \% \text { buffered formalin }\end{array}$ & $\begin{array}{l}24 \\
\text { NS } \\
\text { NS } \\
\frac{1}{2}-24 \\
4-12 \\
\text { NS } \\
\text { NS }\end{array}$ & $\begin{array}{l}4^{\circ} \mathrm{C} \\
\text { Room temperature } \\
\text { NS } \\
\text { Room temperature } 4^{\circ} \mathrm{C} \\
\text { Room temperature } \\
\text { NS } \\
\text { NS }\end{array}$ & \multirow[t]{2}{*}{$\begin{array}{l}\text { Nil } \\
\text { Nil } \\
\text { Trypsin } \\
\text { Nil } \\
\text { DNAse } \\
\text { Nil } \\
\text { Pronase } \\
\text { Trypsin DNAse } \\
\text { DNAse }\end{array}$} & \multirow{2}{*}{$\begin{array}{l}\text { ABC } \\
\text { PAP } \\
\text { ABC } \\
\text { ABC } \\
\text { PAP } \\
\text { ABC } \\
\text { PAP } \\
\text { ABC } \\
\text { ABC } \\
\text { PAP }\end{array}$} \\
\hline Paterson et al (1989) & $\begin{array}{l}\text { Methacarn } \\
\text { Carson's buffered formalin }\end{array}$ & $\begin{array}{l}4-24 \\
24-28\end{array}$ & $4^{\circ} \mathrm{C}$ & & \\
\hline
\end{tabular}

*Used for main study

NS $=$ Not stated

PAP = Peroxidase anti-peroxidase.

ABC = Avidin-biotin complex. 
7 Weintraub J, Weintraub D, Redard $M$, Vassilakos $P$. Evaluation of estrogen receptors by immunochytochemistry on fine-needle aspiration biopsy specimens form breast tumours. Cancer 1987;60:1163-72.

8 Parl FF, Posey YF. Discrepancies of the biochemical and immunohistochemical estrogen receptor assays in breast cancer. Hum Pathol 1988;19:960-6.

9 Di Fronzo G, Clemente C, Cappelletti V, et al. Relationship between ER-ICA and conventional steroid receptor assays in human breast cancer. Breast Cancer Treat Res in human breas

10 Scheres HME, De Goeij AFPM, Rousch MJM, et al. Quantification of oestrogen receptors in breast cancer: radiochemical assay on cytosols and cryostat sections compared with semiquantitative immunocytochemical analysis. J Clin Pathol 1988;41:623-32.

11 Bacus S, Flowers JL, Press MF, Bacus JW, McCarty KS (Jr). The evaluation of estrogen receptor in primary breast carcinoma by computer-assisted image analysis. Am J Clin Pathol 1988;10:233-9.

12 Cheng L, Binder SW, Fu YS, Lewin KJ. Demonstration of estrogen receptors by monocloncal antibody in formalinestrogen receptors by monocloncal antibody in fo

13 Shimada A, Kimura S, Abe K, et al. Immunocytochemical staining of estrogen receptor in paraffin sections of human breast cancer by use of monoclonal antibody: comparison with that in frozen sections. Proc Natl Acad Sci USA 1985;82:4803-7.

14 De Rosa CM, Ozzello L, Greene GL, Habif DV. Immunostaining of estrogen receptor in paraffin sections of breast carcinomas using monoclonal antibody D75 P3. effects of fixation. Am J Surg Pathol 1987;11:943-50.

15 Shintaku P, Said W. Detection of estrogen receptors with monoclonal antibodies in routinely processed formalinfixed paraffin sections of breast carcinoma. Am J Clin fixed paraffin sections
Pathol 1987;87:161-7.
16 Marchetti E, Querzoli R, Moncharmont B, et al. Immunocytochemical demonstration of estrogen receptors by monoclonal antibodies in human breast cancer: correlation with estrogen receptor assay by dextran-coated charcoal method. Cancer Res 1987;47:2508-13.

17 Poulsen HS, Ozello L, King WJ, Greene GL. The use of monoclonal antibodies to estrogen receptors (ER) for immunoperoxidase detection of ER in paraffin sections of human breast cancer tissue. $J$ Histochem Cytochem human breast

18 Andersen J, Orntoft T, Poulsen HS. Semiquantitative oestrogen receptor assay in formalin-fixed paraffin sections of human breast cancer tissue using monoclonal antibodies. Br J Cancer 1986;53:691-4.

19 Abbott ER-ICA monoclonal. Wokingham: Abbott Laboratories, Diagnostic Division, 1986

20 Hawkins RA, Hill A, Freedman B. A simple method for the determination of oestrogen receptor concentration in breast tumours and other tissues. Clin Chim Acta 1975; 64:203.

21 Carson FL, Martin JH, Lynn JA. Formalin fixation for electron microscopy; a re-evaluation. Am J Clin Pathol electron microscop

22 Koenders T, Benraad TJ. Quality control of oestrogen receptor assays in the Netherlands. Breast Cancer Treat Res 1983;3:250-66.

23 Said JW, Shintaku P. Detection of estrogen receptors with monoclonal antibodies in paraffin sections. Am J Clin Pathol 1988;90:649-52.

24 Andersen J, Poulsen HS. Immunohistochemical analysis of estrogen receptors (ER) using formalin-fixed paraffinembedded breast cancer tissue: correlation with clinical endocrine response. J Steroid Biochem 1988;30:337-9.

25 Breast cancer screening. Report of the health ministers of England, Wales, Scotland and Northern Ireland. London: HMSO, 1986. 